\title{
РЕГУЛИРУЮЩИЕ ПРЕРОГАТИВЫ ЕВРОПЕЙСКОГО СОЮЗА: ВОПРОСЫ СУДЕБНОГО И ПОЛИТИЧЕСКОГО КОНТРОЛЯ ИХ РЕАЛИЗАЦИИ
}

Аннотация. В статье проводится анализ субсидиарности как принщипа, имеющего двойственную - и политическую, и правовую - природу. Это предопределяет структуру исследования: основное внимание автором уделяется вопросам судебного и политического контроля соблюдения принщипа субсидиарности в законодательной деятельности Европейского Союза по вопросам, не отнесенным кего исключительной компетенции и, прежде всего, по вопросам его совместной с государствами-членами компетенции. В первой части работь автором анализируется практика Суда Европейского Союза по рассмотрению дел о нарушении наднациональными институтами принципа субсидиарности. Во второй части работь автором анализируется практика применения принципа субсидиарности в законодательном процессе Европейского Союза в рамках так называемого субсидиарного контрольного механизма и его прочедур «желтых» и «оранжевых» карт, инициируемых начиональными парламентами государств-членов Европейского Союза. При написании статьи автором использовались аргументативный, эмпирический, логический и нормативный методы исследования. Причем основные выводы и предложения строятся на использовании аргументативного метода в связи с недостаточностью и ограниченностью судебной практики (всего лишь десять дел) и нормативного материала (всего лишь одна статья в учредительных договорах ЕС) по исследуемому вопросу. Научная новизна исследования состоит в том, что принцип субсидиарности рассматривается автором в контексте законодательной деятельности ЕС не только с позиции политического средства защиты национальных законодательных прерогатив, но и с позищии правового ограничителя реализации наднациональных регулирующих прерогатив, обладающего юрисдикционной силой. B статье оценивается эффективность работы субсидиарности как политического (через субсидиарный контрольный механизм), так и правового (через судебное рассмотрение дел) принщипа. Делаются выводы о значимости и перспективности использования принции а субсидиарности в качестве "ограничителя" реализации регулирующих прерогатив ЕС. В заключительной части исследования, автором высказываются также суждения о возможности использования опыта ЕС, связанного с применением субсидиарности в качестве принципа, ограничивающего реализаџию наднациональных регулируюших прерогатив, в нашей стране, где проблема чрезмерной активности федерального законодателя при регулировании вопросов сферы совместного ведения не теряет своей актуальности вот уже с 2000-х годов.

Ключевые слова: Европейский Союз, принщип субсидиарности, совместная компетенция, регулирующие прерогативы, начиональные парламенты, субсидиарный контрольный механизм, желтая карта, Суд Европейского Союза, Российская Федерация, кооперативный федерализм.

Abstract: This article presents the analysis of subsidiarity as the principle containing the dualpolitical and legal nature. Thus, special attention is given to the questions of judicial and political control over compliance with the principle of subsidiarity in EU legislative activity regarding the questions that are not referred to as of its explicit competence, and primarily, the topic its joint 
competence with the member-states. In the first part of the article, the author analyzed the practice of the Court of Justice of the European Union on the case on violation of the principle of subsidiarity by the supranational institutions. In the second part, the author examines the practice of application of the principle of subsidiarity in the EU legislative process within the framework of the so-called subsidiary control mechanism and its procedures of the "yellow" and "orange" cards, initiated by the EU member-states national parliaments. The scientific novelty consists in the position that the principle of subsidiarity is being viewed in the context of EU legislative activity not only from the perspective of political means aimed at protection of the national legislative prerogatives, but also from the perspective of legal limitation of realization of the supranational regulatory prerogatives, possessing jurisdictional power. The article assesses the efficiency of the work of subsidiarity as political (through the subsidiary control mechanism), as well as legal (through the court case hearing) principle. The author expresses an opinion on possibility of implementation of the principle of subsidiarity as the principle that limits the realization of supranational regulatory prerogative in Russia, where the problem of excessiveness activeness of the federal legislator in regulation of the questions of joint competence does not lose its relevance since 2000's.

Keywords: Yellow card, subsidiarity control mechanism, national parliaments, regulatory prerogatives, shared competence, subsidiarity principle, European Union, Court of Justice of the European Union, Russian Federation, cooperative federalism.

\section{Введение}

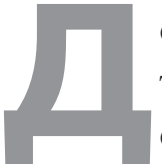
оговором о пересмотре учредительных актов Европейских сообществ и Европейского Союза, подписанным в Лиссабоне в 2007 году и вступившим в силу 13 декабря 2009 года [1, с. 603], (далее - Лиссабонский договор) принцип субсидиарности помещен между принципом наделения компетенцией и принципом пропорциональности. И если первый относится к существованию самой компетенции ЕC, то второй ограничивает ее природу и интенсивность при совершении институтами Европейского Союза (далее EC) конкретных действий. Работая во взаимосвязи с этими двумя однопорядковыми, но различающимися по механизму действия принципами, субсидиарность выступает в праве ЕС принципом реализации регулирующих (законодательных) прерогатив наднациональных институтов в сферах, не отнесенных к исключительной компетенции
EC, и, прежде всего, в сферах его совместной с государствами-членами компетенции.

Такой функциональный подход к пониманию и применению принципа субсидиарности, во-первых, полностью согласуется с правовыми позициями Суда Европейского Союза (далее - Суд ЕС) о том, что принцип субсидиарности является критерием проверки вторичного законодательства ЕС [2], ограничивающим реализацию законодательных прерогатив ЕС [3]. Во-вторых, в целом отражает утвердившуюся и широко распространившуюся в зарубежных академических кругах точку зрения о том, что суть принципа субсидиарности в развитии интеграционных процессов состоит в позиционировании его в качестве «политического принципа на законодательной арене» (Дж. Берманн [4]) и «ограничителя действий законодателя Союза» (И. Купер [5], Дж. Дэвис [6], М. Кумм [7], Дж. Луис [8], Р. Шульц [9]). Как следствие, данный подход получил окончательное развитие в 
Лиссабонском договоре, одной из новаций которого стало повышение эффективности применения принципа субсидиарности в законодательном процессе ЕС за счет учреждения так называемого субсидиарного контрольного механизма (далее - СКМ).

Впервые на основе норм учредительного договора национальным парламентам государств-членов ЕС предоставлена возможность напрямую направлять в наднациональные институты, инициировавшие законопроект ЕС (как правило, в Комиссию $\mathrm{EC})$, свои заключения о нарушении данным законопроектом ЕС принципа субсидиарности. Безусловно, это нововведение не только повысило роль национальных парламентов в наднациональном регулировании, которые стали «сторожевыми псами принципа субсидиарности» [5, с. 283], но и качественно поменяло тактику поведения наднациональных институтов при обосновании ими необходимости разработки и принятия конкретного законодательного акта ЕС по вопросам, не отнесенным к его исключительной компетенции. Можно сказать, что для европейского законодателя СКМ стал стимулом подумать дважды, прежде чем использовать регулирующие прерогативы ЕС.

\section{О субсидиарности \\ как динамичной категории в праве ЕС}

Несмотря на свой полисемичный характер, принцип субсидиарности может быть определен как принцип, в соответствии с которым даже самые маленькие территориальные, социальные и политические единицы могут иметь все права, в которых они нуждаются для того, чтобы регулировать свои собственные дела свободно и эффективно. В свою очередь, это требует ограничения сфер ответственности (выполняемых функций) более крупных единиц теми вопросами, которые могут быть осуществлены самосто- ятельно более мелкими единицами. Можно сказать, что принцип субсидиарности имеет двойной аспект применения: негативная субсидиарность требует не вмешательства более крупных единиц в то, что более мелкие единицы смогут сделать собственными силами для себя, тогда как позитивная субсидиарность требует вмешательства более крупных единиц в дела более мелких в тех случаях, когда последние нуждаются в помощи. Эта двойственность подчеркивает первозданную природу субсидиарного подхода к организации и осуществлению власти: субсидиарность не только создает ограничение на вмешательство со стороны вышестоящих властей в дела нижестоящих властей, но также и обязательство для такого вмешательства, дабы дать нижестоящим властям средства и возможности для полноценной реализации их собственных целей и задач.

Разделительную линию между двумя аспектами (негативным и позитивным) принципа субсидиарности не всегда просто установить. Поскольку субсидиарность основывается на идее о том, что власть принадлежит тому, кто ближе находится к решению возникшей проблемы, то уместно было бы предположить, что субсидиарность отдает, по крайней мере, с теоретической точки зрения, определенную степень предпочтения более малым единицам [10]. Однако субсидиарность не отдает предпочтений и не создает презумпций решениям как более «лучшим» какого-либо уровня власти, но требует баланса за счет сравнительной эффективности таковых. Применительно к осуществлению властных полномочий в любой многоуровневой системе субсидиарность может работать как вверх (в сторону передачи полномочий от единиц центру), так и вниз (в сторону передачи полномочий от центра единицам). Результат, получаемый в каждом конкретном случае, будет зависеть 
от оценки способности более мелких единиц справляться эффективно с имеющимися у них делами (вопросами, находящимися в их компетенции). Таким образом, субсидиарность это ни централизующий, ни децентрализующий принцип, но, скорее всего, динамичный принцип, который стремится к тому, чтобы «дать баланс сил, целей и возможностей, превращая их соотношение в систему» [11]. Субсидиарность дает гибкость управлению, устанавливая баланс между уважением к разнообразию и необходимостью обеспечения целостности.

В европейских интеграционных процессах принцип субсидиарности используется в качестве инструмента, позволяющего каждому участнику, осуществляя свою роль в процессе принятия политических и (или) правовых решений, «вкладывать в него свой собственный смысл» [12]. Это очень важно в деле продвижения интеграционного развития. Но при всей своей гибкости, динамичности, неприемлемости жестких рамок (возможно, по этой причине в праве ЕС до сих пор отсутствуют четкие критерии его применения) принцип субсидиарности довольно жестко регулирует реализацию регулирующих прерогатив ЕС. Как следует из абзаца первого параграфа 3 статьи 5 Договора о Европейском Союзе в редакции Договора о пересмотре учредительных актов Европейских сообществ и Европейского Союза, подписанного в Лиссабоне в 2007 году [1] (далее - ДЕС), «согласно принципу субсидиарности Союз в сферах, которые не относятся к его исключительной компетенции, действует лишь тогда и в такой степени, в какой цели предполагаемого действия не могут достаточным образом быть достигнуты государствами-членами на центральном, региональном или местном уровне, но, ввиду масштабов или последствий предполагаемого действия могут быть лучше достигнуты на уровне Союза».
Мера действий, предпринимаемых ЕС в соответствии с принципом субсидиарности, должна быть ограничена тем, что необходимо для заполнения «policy gap» ${ }^{1}$, оставленного государствами-членами как следствие их частичной или полной неспособности достичь цели предполагаемого действия достаточным образом. По словам К. Ленартса, «конкурирующая ценность, защищаемая таким выражением принципа субсидиарности, это суверенитет государств-членов» [13]: остаточные полномочия государств-членов не должны быть затронуты более чем это необходимо для того, чтобы и ЕС, и его государства-члены были способны действовать эффективно, в духе лояльного сотрудничества друг к другу, совместно достигая поставленные цели.

\section{О реализации регулирующих прерогатив ЕC}

Согласно принципу наделения компетенцией ЕС действует по правилу intra vires, то есть только в пределах компетенции, которую предоставили ему в учредительных договорах государства-члены для достижения целей, установленных этими договорами. Любая компетенция, не предоставленная ЕС в договорах, принадлежит государствам-членам (параграф 2 статьи 5 ДЕС). Данный подход отражает сложившуюся еще в 1950-х годах (при учреждении Европейских сообществ) и сохраняющуюся по сей день специфику наделения ЕС компетенцией: разные сферы отношений передаются государствами-членами в ведение EC не целиком, а лишь применительно к отдельным их аспектам, прямо оговоренным в уполномочивающих статьях учредительных договоров. Поэтому реализация регулирующих прерогатив ЕС осуществляется

\footnotetext{
${ }^{1}$ Политического разрыва. Пер. с анг.
} 
строго в соответствии с так называемыми «правовыми базами» - положениями учредительных договоров, уполномочивающими ЕС на принятие законодательных актов.

«Правовые базы» определяют, по каким конкретным вопросам, в каких целях, в каком порядке, через какие институты и посредством какого вида актов ЕС вправе осуществлять регулирование в подведомственных ему сферах компетенции. Ссылки на них обязательны в преамбуле каждого законодательного акта ЕС, а отсутствие соответствующей ссылки или ее неполное приведение влекут отмену акта Судом ЕС [14].

По своему содержанию «правовые базы», как правило, включают три аспекта, в соответствии с которыми реализуются регулирующие прерогативы EC: субстантивный, инструментальный и институциональный. Суть субстантивного аспекта «правовой базы» сводится к выяснению того, находится ли предмет подлежащего принятию ЕС законодательного акта в пределах полномочий, предоставленных ЕС положениями учредительных договоров. Если да, то в игру вступают два другие аспекта, в соответствии с которыми осуществляется принятие законодательного акта - инструментальный (указывающий на вид акта, как правило, директиву или регламент) и институциональный (определяющий обычную или специальную законодательную процедуру). Если же предмет подлежащего принятию ЕС законодательного акта не вписывается в полномочия ЕС, предусмотренные положениями учредительных договоров, то считается, что ЕС злоупотребляет компетенцией, посягая на остаточные законодательные прерогативы государств-членов, кроме тех случаев, когда другие положения учредительных договоров предоставляют ЕС резервные полномочия в соответствии с так называемыми «статьями-лазейками», которыми можно воспользоваться при отсутствии специальной «правовой базы».
Наиболее широкой по своему регулирующему потенциалу из числа содержащихся в учредительных договорах «статей-лазеек» является статья 352 Римского договора в редакции Лиссабонского договора [1, с. 211] (далее - ДФЕС), исходя из которой Совет может принимать решения по тем вопросам, которые прямо не отнесены к ведению ЕC, но необходимы для достижения целей ЕC, предусмотренных в ДЕС и ДФЕС. По сути, это «open-ended guideline»², который может использоваться для обоснования принятия любых законодательных актов, в том числе направленных на приращение компетенции EC. Последнее имело место, например, в 1976 году, когда на основании статьи 308 Римского договора (нынешней статьи 352 ДФЕС) была принята Директива о равном обращении с мужчинами и женщинами (Directive 76/207 on Equal Treatment for Men and Women), хотя в то время сама цель гендерного равенства даже не присутствовала в учредительном договоре Сообщества.

Наличие «статей-лазеек» свидетельствует о признании в праве ЕС доктрины подразумеваемых полномочий («implied powers»), которая получила поддержку еще в 1980-х годах в решении Суда Европейских сообществ по делу Germany v. Commission [15]. В данном решении Суд, в частности, постановил, что в случае, когда положение учредительного договора возлагает на Комиссию осуществление особой задачи, данное положение должно рассматриваться как «возлагающее на Комиссию в подразумеваемой форме полномочия, существенно необходимые для выполнения этой задачи».

Доктрина подразумеваемых полномочий через применение «статей-лазеек» позволяет ЕС осуществлять регулирование, когда, по мнению его институтов, это необходимо для достижения любых целей, установленных в

\footnotetext{
${ }^{2}$ Открытая норма. Пер. с анг.
} 
учредительных договорах ЕС, даже если ЕС на данный момент не обладает компетенцией для их достижения. С одной стороны, это способствует определенной гибкости в определении и реализации регулирующих прерогатив EC, но, с другой стороны, становится затруднительным определение остаточных регулирующих прерогатив государств-членов ЕС. Как пишет по этому поводу проф. Т. Ланг, «очень трудно представить какое-либо поле деятельности, которое будет постоянно находиться вне полномочий Сообщества» [16], что, конечно же, чрезмерно политизирует решение вопроса о надлежащем уровне правового регулирования.

Установление баланса между доктриной подразумеваемых полномочий, применение которой в праве ЕС делает его компетенцию практически ничем не ограниченной, и принципом субсидиарности, призванным в соответствии с параграфом 3 статьи 5 ДЕС все же ограничивать реализацию неисключительной законодательной компетенции $\mathrm{EC}$, сегодня выступает актуальной задачей для Суда ЕС как единственного толкователя и окончательного применителя норм и принципов права ЕС [17].

\section{О судебном контроле реализации регулирующих прерогатив ЕC}

С вступлением в силу Маастрихтского договора принцип субсидиарности получил юрисдикционную защиту. Впервые в практике Суда ЕС принцип субсидиарности был применен в деле United Kingdom v Council (Working Time) [18]. В нем Великобритания предъявила иск к Совету с целью отмены директивы EC, устанавливавшей максимальное количество часов работы в неделю. По мнению истца, Совет, издавая директиву, не обосновал необходимость введения новой меры в соответствии с принципом субсидиарности, то есть не доказал, что предлагаемая мера могла быть лучше осуществлена ЕC, а не государствами-членами. И хотя Суд ЕС не поддержал истца, подойдя к решению вопроса о соблюдении принципа субсидиарности весьма формально, тем не менее, решение по данному делу стало знаковым для институтов ЕС, реализующих его законодательные прерогативы по вопросам совместной с государствами-членами компетенции. В дальнейшем оно, став хрестоматийным, послужило одним из поводов для разработки и принятия решительных мер по совершенствованию механизма соблюдения принципа субсидиарности в законодательном процессе ЕС (посредством учреждения СКМ). До рассмотрения этого дела вопрос о применении принципа субсидиарности был поставлен перед Судом первой инстанции в феврале 1995 года в деле Vereniging van Samenwerkende Prijsregelende Organisaties in de Bouwnijverheid and others $v$ Commission of the European Communities [19]. Однако Суд первой инстанции избежал применения принципа субсидиарности, указав, что принцип субсидиарности не может до вступления в силу Маастрихтского договора являться общим принципом права, на основании которого может оспариваться законность актов Сообщества. Эта позиция затем была подтверждена Судом ЕС в объединенном деле Hilmar Kellinghusen v. Amt für Landund Wasserwirtschaft Kiel And Ernst-Detlef Ketelsen v. Amt für Land-und Wasserwirtschaft Husum [20].

За период почти что в два десятилетия имело место только десять исков в связи с нарушениями законодательными актами EC принципа субсидиарности [21]. При рассмотрении большинства из них Суд ЕС, по оценкам многих европейских исследователей, применяет принцип субсидиарности «в формальной и осторожной форме» [22], используя его в качестве «инструмента низкой интервенции и минимальной проверки» 
[23]. Вынося решения по таким делам, Суд ЕС оценивает соблюдение принципа субсидиарности с точки зрения формально-процедурных требований, избегая анализа сравнительной эффективности действий, предполагаемых к осуществлению на уровне ЕС, и полагаясь на мнение самих институтов - инициаторов соответствующего законопроекта.

Так, в деле Netherlands $v$ Parliament and Council [24] Нидерланды поставили перед Судом ЕС вопрос о несоответствии директивы о биотехнологических изобретениях принципу субсидиарности, на который Суд ЕС ответил следующим образом: цель директивы, состоящая в обеспечении устойчивого функционирования внутреннего рынка ЕС в сфере биотехнологических изобретений, не может быть достигнута действиями, предпринимаемыми государствами-членами самостоятельно. По сути, Суд ЕС повторил преамбулу директивы, сделав в конце вывод о том, что принцип субсидиарности соблюден «имплицитно, но очевидно». Аналогичным образом Суд ЕС высказался о соблюдении принципа субсидиарности в деле British American Tobacco (Investments) and Imperial Tobacco [25].

В деле Federal Republic of Germany $v$ European Parliament \& Council [26] Германия, оспаривая директиву ЕC, нацеленную на введение во всех государствах-членах обязательной системы гарантий банковских вкладов, указала на нарушение законодательными институтами ЕС своего обязательства представить достаточные основания для реализации законодательных прерогатив в данной сфере банковской индустрии. Примечательно, что Германия ссылалась не на нарушение оспариваемой директивой принципа субсидиарности, а на то, что законодатель ЕС не представил, как того требует статья 5 Протокола о применении принципов субсидиарности и пропорцио- нальности, принятого в 2007 году вместе с Лиссабонским договором [1, с. 396] (далее - Протокол), доказательства соответствия своих действий принципу субсидиарности, то есть не объяснил, почему для достижений целей директивы ею предусматриваются действия только на уровне ЕС. Суд ЕС взял за основу минимальные требования, установленные в одном из своих предыдущих решений [27]. По мнению Суда ЕС, демонстрация со стороны институтов ЕС достаточных оснований необходима только тогда, когда отсутствуют очевидные причины, приведшие ЕС к принятию определенного законодательства. При этом Суд ЕС пояснил, что преамбула оспариваемой директивы ясно отражала позицию законодателя о том, что цель может быть лучше достигнута на уровне ЕС.

Отдельно следует отметить роль Суда ЕС в толковании и применении принципа субсидиарности при рассмотрении дел, затрагивающих свободы передвижения на внутреннем рынке ЕС. Дело в том, что создание внутреннего рынка в соответствии с параграфом 3 статьи 3 ДЕС выступает одной из основных целей ЕС. На функционирование внутреннего рынка ЕС распространяется совместная компетенция ЕС и его государств-членов (пункт «а» параграфа 2 статьи 4 ДФЕС). Это означает, что и $\mathrm{EC}$, и государства-члены могут законодательствовать по вопросам создания и функционирования внутреннего рынка ЕC, поэтому особенно значима роль Суда ЕС в обеспечении обоснованности реализации наднациональными институтами соответствующих регулирующих прерогатив ЕС.

Однако практика показывает, что в таких делах Суд ЕС чаще всего интерпретирует договорные положения в пользу компетенции ЕС, нежели чем его государств-членов и, тем самым, до определенных пределов пренебрегает принципом субсидиарности как ограничителем реализации неисклю- 
чительных регулирующих прерогатив ЕC. Например, Суд ЕС решал дела в пользу $\mathrm{EC}$, изначально не имевшего законодательной компетенции в регулировании сфер образования [28], культуры и спорта [29]. Так, в ставшем уже хрестоматийным деле Union Royale Belge des Sociétés de Football Association and others v Bosman [29] Судом ЕС признано, что вообще регулирование реализации всех фундаментальных свобод в ЕС принадлежит к исключительной компетенции ЕС, тогда как в деле Commission $v$ Belgium [2] Суд ЕС уточнил, что принцип субсидиарности применяется только к вторичному праву ЕС и поэтому не может быть использован для регулирования реализации фундаментальных свобод, закрепленных в учредительных договорах ЕС.

Лишь в редких случаях Суд ЕС принимал решения, ограничивающие реализацию законодательных прерогатив ЕС. Так, в решении по делу Germany v Parliament and Council (Tobacco Advertising) [30] Суд ЕС четко определил, что существование компетенции ЕС в соответствии со статьей 114 ДФЕС не может быть истолковано как предоставление наднациональному законодателю «генерального полномочия регулировать внутренний рынок. В связи с логикой принципа субсидиарности использование статьи 114 ДФЕС обусловлено существованием национальных мер, формирующих барьеры свободному движению или существенно искажающих конкуренцию в пределах Европейского Союза. Наличие же просто несоответствий между национальными законодательствами недостаточно для принятия гармонизирующих мер законодателем Европейского Союза в соответствии со статьей 114 ДФЕС». Решение по данному делу привело к ограничению вмешательства ЕС в регулирование рекламы табака.

В целом же, разрешая споры о необходимости реализации регулирующих прерогатив на уровне ЕС, Суд ЕС интерпретирует принцип субсидиарности как гибкую «правовую базу», позволяющую обосновывать расширение компетенции ЕС, за что справедливо обвиняется экспертами в «судейской политической деятельности» [23, c. 234]. С одной стороны, это связано с тем, что «технически он [принцип субсидиарности] сложен для практического применения» [31]. Применение принципа субсидиарности строится на учете специфики конкретной ситуации и ее ресурсного контекста, который меняется во времени, делая практически невозможной адекватную правовую оценку. Несмотря на признание правовой природы принципа субсидиарности Маастрихтским договором, точные пределы, содержание и критерии применения данного принципа в праве ЕС до сих пор отсутствуют. С другой стороны, прояснение неопределенности по этим вопросам могло бы исходить от Суда $\mathrm{EC}$, который часто проявлял судейский активизм при введении новых правовых доктрин даже без прямо выраженной в учредительных договорах правовой их поддержки (в частности, доктрина прямого действия норм права ЕС и доктрина верховенства права ЕС, не будучи первоначально предусмотренными учредительными договорами, являются, по природе своего возникновения, исключительно «продуктами судебного права» [32], но в случае с принципом субсидиарности остается безмолвным. Поэтому, несмотря на то что учредительные договоры прямо закрепили правовую обязательность соблюдения институтами ЕС принципа субсидиарности при реализации неисключительных регулирующих прерогатив ЕC, его судебное применение не является достаточно эффективным. До сих пор Суд ЕС не аннулировал ни одного законодательного акта ЕС по основанию несоответствия его принципу субсидиарности, хотя юрисдикционную силу последний получил еще в 
1994 году. Учитывая эту осторожность Суда EC, Лиссабонский договор сделал упор на политическую важность предварительного мониторинга соблюдения принципа субсидиарности через СКМ.

\section{О политическом контроле реализации регулирующих прерогатив ЕС}

В соответствии с СКМ любой национальный парламент (или любая палата национального парламента при двухпалатном национальном парламенте) в течение восьми недель со дня передачи на его рассмотрение проекта законодательного акта ЕС может направить в адрес соответствующего института ЕC, ответственного за подготовку проекта законодательного акта ЕС, мотивированное заключение по поводу соответствия последнего принципу субсидиарности. В зависимости от количества мотивированных заключений, статьей 7 Протокола предусмотрено применение двух процедур - процедуры «желтой карты» и процедуры «оранжевой карты» [33]. «Желтая карта» применяется, если мотивированные заключения представляют не менее одной трети (одной четверти в отношении проектов, затрагивающих пространство свободы, безопасности и правосудия) всех голосов, которыми наделены национальные парламенты (каждый национальный парламент или палата национального парламента располагает двумя голосами). В этом случае проект законодательного акта подлежит повторной экспертизе, по результатам которой Комиссия ЕС (если проект исходит от нее) может принять решение оставить его в прежнем виде, изменить или отозвать. Любое решение при этом должно быть мотивированным. «Оранжевая карта» применяется в рамках обычной законодательной процедуры, если мотивированные заключения представляют не менее простого большинства голосов, которыми наделены национальные парламенты. В этом случае проект законодательного акта также подлежит повторной экспертизе, по результатам которой он также может быть оставлен в прежнем виде, изменен или отозван. Однако в случае принятия Комиссией ЕС решения об оставлении проекта в прежнем виде, ею готовится мотивированное заключение, в котором она должна будет обосновать причину, по которой считает предложенный ею проект соответствующим принципу субсидиарности. Это мотивированное заключение Комиссии ЕС, а также мотивированные заключения национальных парламентов подлежат передаче созаконодателям ЕС, которые до окончания первого чтения проверяют проект на предмет его соответствия принципу субсидиарности и если большинством в $55 \%$ членов Совета или большинством поданных голосов в Европейском парламенте законодатель ЕС приходит к выводу о несоответствии проекта законодательного акта принципу субсидиарности, то его дальнейшее рассмотрение не проводится. До настоящего времени ни одной «оранжевой карты» не было инициировано.

С момента вступления в силу Лиссабонского договора национальными парламентами было выпущено только три «желтые карты»: в мае 2012 года (в отношении проекта регламента об осуществлении права на принятие коллективных действий в контексте свободы учреждения и свободы предоставления услуг [34]), в октябре 2013 года (в отношении проекта регламента об учреждении Европейской Прокуратуры [35]) и в мае 2016 года (в отношении поправок в директиву о перемещенных работниках [36]). В первом случае Комиссия ЕС решила отозвать законопроект, но ввиду политического несогласия в Совете, нежели чем в результате возбуждения «желтой карты». Во втором случае Комиссия ЕС решила оставить законопроект без каких-либо из- 
менений, посчитав его соответствующим принципу субсидиарности. В третьем случае Комиссия ЕС также заключила, что законопроект не нарушает принципа субсидиарности, в связи с чем его «отзыв или изменение не требуются» [37]. Таким образом, за семь лет функционирования СКМ Комиссией ЕС был отозван только один законопроект.

Количество мотивированных заключений, выпущенных национальными парламентами за период с 2010 по 2015 годы, также невелико - всего 285. В 2014 году было выпущено 21 мотивированное заключение [38]. В 2015 году - только 8 [39], наименьшее количество с момента введения СКМ. На подавляющее большинство законодательных проектов Комиссии ЕС национальными парламентами не направляются мотивированные заключения.

Оценивая значение СКМ, нельзя согласиться с теми исследователями, с точки зрения которых «желтая карта» представляет собой «скорее беззубую процедуру, оказывающую крайне незначительное влияние на законодательный процесс Европейского Союза» [40]. СКМ несет в себе потенциал «политического инструмента для защиты субсидиарности» [41] и может быть сравнен с традиционным голосованием по выражению недоверия в парламентской системе, важность которого измеряется не тем, как часто политические партии его используют и даже не его результатами, но самим фактом его осуществления. СКМ - это не столько инструмент противодействия законодательному процессу ЕС, сколько «средство коллективного предупреждения о трудностях, подлежащих разрешению институтами EC» [42]. Данный механизм используется национальными парламентами для того, чтобы высказаться напрямую. И хотя национальные парламенты выражают свои мнения индивидуально, налаживание взаимодействия между ними чрезвычайно важно.
Фактически СКМ работает через межпарламентский диалог. Все три «желтые карты» были ожидаемым результатом «network»", сложившейся между национальными парламентами, как минимум с 2009 года [43], которая, основываясь на близких и прямых отношениях национальных парламентариев с их гражданами, тем самым, «легитимирует законотворчество Европейского Союза» [44], делая его «более открытым и понятным по причинам и методам осуществления» [45]. В этом смысле СКМ выступает в качестве «приводного ремня между гражданами ЕС, их объединениями, заинтересованными лицами и законодательным процессом ЕС» [46], и именно национальные парламенты, участвуя в СКМ как «институционные акторы» [23] (а не просто технические органы, оперирующие юридическими терминами), обладающие богатейшей практикой законодательного урегулирования отношений, призваны Лиссабонским договором «добавить европейскому законодательному процессу существенную политическую ценность» [47].

\section{Некоторые выводы и предложения}

Практика применения принципа субсидиарности в законодательной политике ЕС интересна не только с точки зрения использования данного принципа в качестве правового ограничителя реализации законодательных прерогатив ЕС, но и в качестве организационно-политического способа защиты национальных законодательных интересов государств-членов ЕС посредством участия их национальных парламентов в СКМ. И этот опыт ЕС может представлять определённый интерес для совершенствования реализации федеральной законодательной политики в нашей стране.

${ }^{3}$ Сеть. Пер. с анг. 
Правовой режим остаточной компетенции в ЕС похож на правовой режим остаточной компетенции в Российской Федерации (РФ): любая компетенция, не предоставленная в учредительных договорах ЕС, принадлежит его государствам-членам. Относительно похож и правовой режим законодательной реализации совместной компетенции: правом издавать законодательные акты обладают и ЕС, и отдельные государства-члены ЕС с той лишь разницей (весьма существенной!), что последние могут делать это тогда, когда ЕС не воспользовался своей компетенцией или прекратил ее осуществление. Но при всей видимой схожести правовых конструкций фактическая реализация совместных законодательных прерогатив строится на разных подходах, обеспечивающих принципиально разную степень самостоятельности государств-членов ЕС и соответственно субъектов РФ в регулировании искомых вопросов. Если субъектам РФ приходится ждать федерального законодателя, который, как показывает практика, в каждом конкретном случае по своему усмотрению определяет в федеральном законе свои полномочия и тем самым решает, что же останется региональным законодателям для их собственного урегулирования (после реализации федеральных законодательных прерогатив), то государства-члены ЕС по своему усмотрению уступают наднациональному законодателю ровно столько вопросов, сколько они считают необходимым для достижения совместных целей в интеграционном развитии.

Соблюдение самостоятельных законодательных прерогатив субъектов РФ пока что лежит вне поля зрения российского законодателя, хотя общепризнано, что наличие таких прерогатив представляет собой наиболее существенный аспект компетенционной самостоятельности субъектов РФ, от правового решения которого во многом будет зависеть эффективность проводимых федеративных реформ [48]. Региональный законодательный акт должен быть не дополнительным, а основным звеном в механизме правового регулирования отношений по вопросам собственных полномочий органов субъектов РФ, не «частью, позволяющей снять абстрактность норм федеральных законов» [49], а правовым инструментом, позволяющим комплексно и системно урегулировать искомые отношения согласно региональным потребностям, интересам и ресурсам. «Центр тяжести» по реализации законодательных прерогатив по вопросам, не отнесенным к исключительному ведению РФ, должен находиться в субъектах РФ. Именно в таком подходе реализуется историческая логика конституционного регулирования разграничения предметов ведения и полномочий (компетенции) между органами государственной власти РФ и органами государственной власти субъектов РФ.

Компетенция субъектов РФ первична. Компетенция РФ имеет производный характер, так как получена от субъектов РФ: путем заключения Федеративного договора от 31 марта 1992 года органы государственной власти субъектов РФ «передали (курсив автора - О.П.) в ведение федеральных органов государственной власти Российской Федерации полномочия». Позднее, этот подход, известный в теории как принцип наделения компетенцией, получил закрепление в статье 73 Конституции РФ, согласно которой остаточный, то есть «открытый» характер предметов ведения имеют именно субъекты РФ. Поэтому законотворчеством «вне полномочий РФ по предметам совместного ведения» (статья 73 Конституции РФ) должны заниматься именно региональные законодатели, ближе всего находящиеся к гражданам, проживающим на территориях конкретных субъектов РФ, и лучше всего знающие специфику возникающих между гражданами отношений, тогда как 
роль федерального законодателя должна быть сведена к изданию норм, имеющих универсальное значение как для него самого (федерального законодателя), так и для законодателя в большинстве или во всех субъектах РФ. Иными словами, федеральные законы, регулирующие предметы совместного ведения и в особенности вопросы осуществления собственных полномочий органов субъектов РФ, следует принимать на субсидиарной основе. Признание в конституционной судебной практике еще в 1996 году [50] права субъектов РФ на опережающее законодательное регулирование вопросов сферы совместного ведения подтверждает реализуемость такого подхода в принципе. При этом, руководствуясь критерием универсальности федерального законодательного регулирования, Конституционный Суд РФ в 1997 году [51] отметил, что признание за субъектами РФ права осуществлять опережающее регулирование не дает им автоматически полномочий по решению в полном объеме вопросов, имеющих универсальное значение для всех субъектов РФ, и в силу этого подлежащих урегулированию федеральным законом.

Можно сказать, что в нашей стране уже созданы определенные правовые предпосылки для применения субсидиарности как нормативного принципа, нацеленного на упорядочение осуществления совместной регулирующей компетенции. Провозглашенное в части 3 статьи 5 Конституции РФ единство системы государственной власти делает всех ее носителей, независимо от уровня осуществления, одинако ответственными за должную степень эффективности государственного управления. Само возникновение и закрепление в Конституции РФ (статья 72) сферы совместного ведения обусловлено объективными процессами федерализации, требующими сотрудничества и солидарной ответственности федерации и ее субъектов. Это значит, что предметы совместного ведения, прежде всего, это совместные полномочия, которые должны реализовываться совместными усилиями. «Наиболее всего этому - совместному осуществлению общих полномочий - адекватна концепция субсидиарности» [52], которая по своей социально-правовой сути близка концепции государственно-правового института совместного ведения. Именно в государстве, придерживающемся кооперативной модели федерализма, реализация федеральных законодательных полномочий по предметам совместного ведения должна осуществляться на субсидиарной основе, ведь основная идея федерализма, равно как и идея субсидиарности, состоит в следующем: не забирай у других то, что они с успехом могут сделать сами!

\section{Библиография:}

1. Европейский Союз: Основополагающие акты в редакции Лиссабонского договора с комментариями. М.: ИНФРА-М, 2008.

2. Case C-11/95, Commission v Belgium. URL: http// curia.europa.eu (дата обращения 12.09.2016).

3. Case C-376/98, Germany v Parliament and Council (Tobacco Advertising). URL: http// curia.europa. еu (дата обращения 12.09.2016).

4. Bermann G.A. Taking Subsidiarity Seriously: Federalism in the European Community and the United States // Columbia Law Review. 1994. Vol. 94. Iss. 2. P. $331-456$.

5. Cooper I. The Watchdogs of Subsidiarity: National Parliaments and the Logic of Arguing in the EU // Journal Common Market Studies. 2002. Vol. 44. Iss. 2. P. 281 - 304.

6. Davies G. Subsidiarity: The Wrong Idea, in the Wrong Place, at the Wrong Time // Common Market Law Review. 2006. Vol. 43. Iss. 1. P. 63-84. 
7. Kumm M. Constitutionalizing Subsidiarity in Integrated Markets: The Case of Tobacco Regulation in the European Union // European Law Review. 2006. Vol. 12. Iss. 4. P. 503 - 533.

8. Louis J. - V. National Parliaments and the Principle of Subsidiarity: Legal Options and Practical Limits // European Constitutional Law Review. 2008. Vol. 4. Iss. 3. P. 429 - 459.

9. Schütze R. Subsidiarity after Lisbon: Reinforcing the Safeguards of Federalism? // Cambridge Law Journal. 2009b. Vol. 68. Iss. 3. P. 525 - 536.

10. Hogg P.W. Subsidiarity and the Division of Powers in Canada. Canada, 1993. P. 345.

11. Breton A., Cassone A. \& Fraschini A. Decentralization and Subsidiarity: Toward A Theoretical Reconciliation. 1998. P. 21.

12. Сиджански Д. Федералистское будущее Европы: от Европейского Сообщества до Европейского Союза. М., 1998. С. 241.

13. Lenaerts K. The Principle of Subsidiarity and the Environment in the European Union: Keeping the Balance of Federalism // Fordham International Law Journal. 1993. Vol. 17. Iss. 4. P. 883.

14. Case C-325/91, France v Commission. URL: http// curia.europa.eu (дата обращения 12.09.2016).

15. Joined cases 281, 283-5, 287/85, Germany v. Commission. URL: http// curia.europa.eu (дата обращения 12.09.2016).

16. Lang T. EC Constitutional Law: the Division of Powers between the Community and Member States. NILQ, 1988. P. 209.

17. Weiler J. H. The Constitution of Europe "Do The New Clothes Have An Emperor?" And Other Essays on European Integration. Cambridge: Cambridge University Press, 1999. P. 332.

18. Case C-84/94, UK v Council. URL: http// curia.europa.eu (дата обращения 12.09.2016).

19. Case T-29/92, Vereniging van Samenwerkende Prijsregelende Organisaties in de Bouwnijverheid and others v Commission of the European Communities. URL: http// curia.europa.eu (дата обращения 12.09.2016).

20. Joined Cases C-36/97 and C-37/97, Hilmar Kellinghusen v Amt für Land-und Wasserwirtschaft Kiel And Ernst-Detlef Ketelsen v Amt für Land-und Wasserwirtschaft Husum. URL: http// curia.europa. eu (дата обращения 12.09.2016).

21. Craig P. Subsidiarity: a Political and Legal Analysis // Journal of Common Market Studies. 2012. Vol. 50. P. 80.

22. Lindseth P. Equilibrium, Demoi-cracy, and Delegation in the Crisis of European Integration // German Law Journal. 2014. Vol. 15. P. 558.

23. De Burca G. The Principle of Subsidiarity and the Court of Justice as an Institutional Actor // Journal of Common Market Studies. 1998. Vol. 36. P. 225.

24. Case C-377/98, Netherlands v Parliament and Council. URL: http// curia.europa.eu (дата обращения 12.09.2016).

25. Case C-491/01, British American Tobacco (Investments) and Imperial Tobacco. URL: http// curia. europa.eu (дата обращения 12.09.2016).

26. Case 233/94, Federal Republic of Germany v European Parliament \& Council of the European Communities. URL: http// curia.europa.eu (дата обращения 12.09.2016).

27. Case 411/93, French Republic v Commission of the European Communities. URL: http// curia.europa. еu (дата обращения 12.09.2016).

28. Case C-9/74, Casagrande v Landeshauptstadt München. URL: http// curia.europa.eu (дата обращения 12.09.2016).

29. Case C-415/93, Union Royale Belge des Sociétés de Football Association and others v Bosman. URL: http// curia.europa.eu (дата обращения 12.09.2016).

30. Case C-380/03, Federal Republic of Germany v European Parliament and Council of the European Union (Tobacco Advertising). URL: http// curia.europa.eu (дата обращения 12.09.2016).

31. Syrpis Ph. In Defense of Subsidiarity // Oxford Journal of legal Studies. 2004. Vol. 24. P. 330.

32. Waele H. and Vleuten A. Judicial Activism in the European Court of Justice - The Case of LGBT Rights // Michigan State International Law Review. 2013. Vol. 19. P. 644-665.

33. Annual report 2012 on subsidiarity and proportionality: Report from the Commission, Brussels, 2013. $\operatorname{COM}(2013) .566$ final. P. 3. 
34. European Commission. Proposal for a Council Regulation on the exercise of the right to take collective action within the context of the freedom of establishment and the freedom to provide services. COM (2012) 130 final. 21 March 2012.

35. European Commission. Proposal for a Council Regulation on the establishment of the European Public Prosecutor's Office. COM (2013) 534 final. 17 July 2013.

36. European Commission. Proposal for a Directive of the European Parliament and of the Council amending Directive 96/71/EC of The European Parliament and of the Council of 16 December 1996 concerning the posting of workers in the framework of the provision of services. COM (2016) 128 final. 8 March 2016.

37. European Commission. Communication from the Commission to the European Parliament, the Council and the National Parliaments on the Proposal for a Directive amending the Posting of Workers Directive, with regard to the Principle of Subsidiarity, in accordance with Protocol 2. COM (2016) 505 final. 20 July 2016.

38. European Commission. Annual Report on Subsidiarity and Proportionality. COM (2015) 315 final. 2 July 2015.

39. European Commission. Annual Report 2015 on Subsidiarity and Proportionality. COM (2016) 469 final. 15 July 2016.

40. Raunio T. Destined for Irrelevance? Subsidiarity Control by National Parliaments. Working Paper 26/2010. Elcano Royal Institute, Madrid, 2010. P. 2. URL: http://www.realinstitutoelcano.org/ (дата обращения: 12.09.2016).

41. Moens G. Trone J. The Principle of Subsidiarity in EU Judicial and Legislative Practice: Panacea or Placebo // Journal of Legislation. 2015. Vol. 41. P. 96.

42. Paulo M. National Parliaments in the EU: after Lisboa and beyond subsidiarity-The (positive) side-effects and (unintended) achievements of the Treaty provisions. OPAL Online Paper. 2012. №. 5/2012. P. 13. URL: http:// www.opal-europe.org (дата обращения: 12. 09. 2016).

43. European Commission. Report from the Commission on subsidiarity and proportionality (18th report on Better Lawmaking covering the year 2010). COM (2011) 344 final. 10 July 2011.

44. Paskalev V. Lisbon Treaty and the Possibility of a European Network Democracy: Working Paper Law. European University Institute. 2009. P. 1, 9, 10.

45. Weatherill S. Finding a Role for the Regions in Checking the EU's Competence / In S. Weatherill and U. Bernitz (eds.) The Role of Regions and Sub-national Actors in Europe. Oxford-Portland, OR: Hart Publishing, 2005. P. 147.

46. Barret G. The Early Warning System: some early reflections: Paper delivered on the occasion of the Conference "Parliaments in the European Union after Lisbon", held in Maastricht on the 23rd of February 2012. P. 16.

47. Horsley T. Subsidiarity and the European Court of Justice: Missing Pieces in the Subsidiarity Jigsaw? // Journal of Common Market Studies. 2011. P. 3.

48. Умнова И.А. Совместное ведение Российской Федерации и ее субъектов как предмет конституционного регулирования // Журнал российского права. 1999. № 11. URL: http:/consultant.ru (дата обращения 14.01.2015).

49. Степанова В.М. О практике «опережающего» правотворчества субъектов Российской Федерации по предметам совместного ведения // Законодательство и экономика. 2008. № 6. URL: http:// consultant.ru (дата обращения 14.01. 2015).

50. По делу о проверке конституционности ряда положений Устава - Основного Закона Читинской области: Постановление Конституционного Суда Российской Федерации от 1 февраля 1996 года № 3-П // Собрание законодательства Российской Федерации. 1996. № 7. Ст. 700.

51. По делу о проверке конституционности положений статей 18 и 20 Закона Российской Федерации «Об основах налоговой системы в Российской Федерации»: Постановление Конституционного Суда Российской Федерации от 21 марта 1997 года № 5-П // Собрание законодательства Российской Федерации. 1997. № 13. Ст. 1602.

52. Энтин Л.М. Право Европейского Союза. Новый этап эволюции: 2009-2017 годы. М.: Изд-во «Аксиом», 2009. С. 59. 
53. Кононенко Д.Х. Осуществление контрольных полномочий парламентом Российской Федерации: вопросы теории и практики // Право и политика. 2015. № 11. C. 1536 - 1543. DOI: 10.7256/1811-9018.2015.11.16823.

\section{References (transliterated):}

1. Bermann G.A. Taking Subsidiarity Seriously: Federalism in the European Community and the United States // Columbia Law Review. 1994. Vol. 94. Iss. 2. R. 331 - 456.

2. Cooper I. The Watchdogs of Subsidiarity: National Parliaments and the Logic of Arguing in the EU // Journal Common Market Studies. 2002. Vol. 44. Iss. 2. R. $281-304$.

3. Davies G. Subsidiarity: The Wrong Idea, in the Wrong Place, at the Wrong Time // Common Market Law Review. 2006. Vol. 43. Iss. 1. P. 63-84.

4. Kumm M. Constitutionalizing Subsidiarity in Integrated Markets: The Case of Tobacco Regulation in the European Union // European Law Review. 2006. Vol. 12. Iss. 4. P. 503 - 533.

5. Louis J. - V. National Parliaments and the Principle of Subsidiarity: Legal Options and Practical Limits // European Constitutional Law Review. 2008. Vol. 4. Iss. 3. R. 429 - 459.

6. Schütze R. Subsidiarity after Lisbon: Reinforcing the Safeguards of Federalism? // Cambridge Law Journal. 2009b. Vol. 68. Iss. 3. R. 525 - 536.

7. Hogg P.W. Subsidiarity and the Division of Powers in Canada. Canada, 1993. R. 345.

8. Breton A., Cassone A. \& Fraschini A. Decentralization and Subsidiarity: Toward A Theoretical Reconciliation. 1998. R. 21.

9. Sidzhanski D. Federalistskoe budushchee Evropy: ot Evropeiskogo Soobshchestva do Evropeiskogo Soyuza. M., 1998. S. 241.

10. Lenaerts K. The Principle of Subsidiarity and the Environment in the European Union: Keeping the Balance of Federalism // Fordham International Law Journal. 1993. Vol. 17. Iss. 4. R. 883.

11. Lang T. EC Constitutional Law: the Division of Powers between the Community and Member States. NILQ, 1988. P. 209.

12. Weiler J. H. The Constitution of Europe "Do The New Clothes Have An Emperor?" And Other Essays on European Integration. Cambridge: Cambridge University Press, 1999. R. 332.

13. Joined Cases C-36/97 and C-37/97, Hilmar Kellinghusen v Amt für Land-und Wasserwirtschaft Kiel And Ernst-Detlef Ketelsen v Amt für Land-und Wasserwirtschaft Husum. URL: http// curia.europa. eu (data obrashcheniya 12.09.2016).

14. Craig P. Subsidiarity: a Political and Legal Analysis // Journal of Common Market Studies. 2012. Vol. 50. P. 80.

15. Lindseth P. Equilibrium, Demoi-cracy, and Delegation in the Crisis of European Integration // German Law Journal. 2014. Vol. 15. P. 558.

16. De Burca G. The Principle of Subsidiarity and the Court of Justice as an Institutional Actor // Journal of Common Market Studies. 1998. Vol. 36. R. 225.

17. Syrpis Ph. In Defense of Subsidiarity // Oxford Journal of legal Studies. 2004. Vol. 24. P. 330.

18. Waele H. and Vleuten A. Judicial Activism in the European Court of Justice - The Case of LGBT Rights // Michigan State International Law Review. 2013. Vol. 19. P. 644-665.

19. Raunio T. Destined for Irrelevance? Subsidiarity Control by National Parliaments. Working Paper 26/2010. Elcano Royal Institute, Madrid, 2010. P. 2. URL: http://www.realinstitutoelcano.org/ (data obrashcheniya: 12.09 .2016$)$.

20. Moens G. Trone J. The Principle of Subsidiarity in EU Judicial and Legislative Practice: Panacea or Placebo // Journal of Legislation. 2015. Vol. 41. P. 96.

21. Paulo M. National Parliaments in the EU: after Lisboa and beyond subsidiarity-The (positive) side-effects and (unintended) achievements of the Treaty provisions. OPAL Online Paper. 2012. №. 5/2012. P. 13. URL: http:// www.opal-europe.org (data obrashcheniya: 12. 09. 2016).

22. Paskalev V. Lisbon Treaty and the Possibility of a European Network Democracy: Working Paper Law. European University Institute. 2009. P. 1, 9, 10. 
DOI: $10.7256 / 2226-6305.2016 .4 .21112$

При цитировании этой статьи сноска на doi обязательна

23. Weatherill S. Finding a Role for the Regions in Checking the EU's Competence / In S. Weatherill and U. Bernitz (eds.) The Role of Regions and Sub-national Actors in Europe. Oxford-Portland, OR: Hart Publishing, 2005. P. 147.

24. Barret G. The Early Warning System: some early reflections: Paper delivered on the occasion of the Conference "Parliaments in the European Union after Lisbon", held in Maastricht on the 23rd of February 2012. P. 16.

25. Horsley T. Subsidiarity and the European Court of Justice: Missing Pieces in the Subsidiarity Jigsaw? // Journal of Common Market Studies. 2011. R. 3.

26. Umnova I.A. Sovmestnoe vedenie Rossiiskoi Federatsii i ee sub"ektov kak predmet konstitutsionnogo regulirovaniya // Zhurnal rossiiskogo prava. 1999. № 11. URL: http://consultant.ru (data obrashcheniya 14.01.2015).

27. Stepanova V.M. O praktike «operezhayushchego» pravotvorchestva sub"ektov Rossiiskoi Federatsii po predmetam sovmestnogo vedeniya // Zakonodatel'stvo i ekonomika. 2008. № 6. URL: http://consultant.ru (data obrashcheniya 14.01. 2015).

28. Entin L.M. Pravo Evropeiskogo Soyuza. Novyi etap evolyutsii: 2009-2017 gody. M.: Izd-vo «Aksiom», 2009. S. 59.

29. Kononenko D.Kh. Osushchestvlenie kontrol'nykh polnomochii parlamentom Rossiiskoi Federatsii: voprosy teorii i praktiki // Pravo i politika. 2015. № 11. C. 1536 - 1543. DOI: 10.7256/1811-9018.2015.11.16823. 